\title{
CIVIL SOCIETY, SHADOW STATE DAN LOCAL STRONGMEN DALAM KAJIAN POLITIK LOKAL
}

\author{
Gili Argenti \\ FISIP Universitas Singaperbangsa Karawang \\ Email: gili.argenti@fisip.unsika.ac.id
}

\begin{abstract}
ABSTRAK
Civil society merupakan kelompok masyarakat bersifat mandiri, dalam sistem demokrasi eksistensinya sangatlah diperlukan sebagai pengawas jalannya roda pemerintahan. Representasi civil society berupa organisasi non pemerintah (ornop) yang menjadi wadah berkumpul masyarakat, di era demokratisasi peran kelompok-kelompok civil society ini sangat penting sebagai kekuataan pengontrol jalannya roda pemerintahan di daerah, diharapkan dengan semakin kuatnya civil society, pembangunan politik ke arah konsolidasi demokrasi. Sehingga anomali demokrasi di daerah seperti kemunculan Shadow State dan Local Strongmen dapat terminimalisir. Tulisan ini merupakan sebuah kajian teoritik tentang arti penting civil society sebagai pilar kekuataan demokrasi di Indonesia.
\end{abstract}

Kata Kunci: Civil Society, Shadow State dan Local Strongmen

\section{ABSTRACT}

Civil society is a group of communities are self-sustaining, democratic system in its existence is absolutely necessary asthe overseer of the operationof the wheels of Government.Representation of civil society in the form of a nonGovernment Organization (non-profit) that becomes thecontainer of gathered people, in this era of democratizationof the role of civil society groups is so important as to buckcontroller course wheels of Government in the region,expected with the more powerful civil society, politicaldevelopment towards the consolidation of democracy. Sothe anomaly of democracy in regions such as the emergenceof Shadow State and Local Strongmen can terminimalisir.This paper is a study of the teoritik about the significance ofcivil society to buck as the pillars of democracy in Indonesia.

Keywords: Civil Society, Shadow State dan Local Strongmen

\section{PENDAHULUAN}

Dalam teori Guillerno O'Donnel ketika kaum prodemokrasi berhasil meraih kekuasaan politik, maka rezim reformis tersebut memasuki tahapan transisi dalam pemerintahanya. Transisi demokrasi ialah interval waktu antara rezim otoriter menuju rezim politik yang lebih demokratis, tahap transisi ini merupakan fase kritis dalam proses menuju demokrasi terkonsolidasi, pemerintah Indonesia pasca Orde Baru, berdasarkan teori O'Donnel memasuki masa transisi, sebuah masa yang sangat menentukan masa depan pembangunan demokrasi politiknya. Pemerintahan baru yang 
terpilih melalui pemilu yang bebas dimana pemerintahan secara de facto harus menghasilkan kebijakankebijakan baru atas kekuasaan eksekutif, legislatif dan yudikatif, yang secara de jure kebijakan tersebut dihasilkan melalui sistem demokrasi baru (Guillerno O’Donell, 1993).

Menurut Eep Saefullah Fatah
(2000), dengan terbentuknya pemerintahan baru setelah pemilu tahun 1999, secara teoritis menandai masuknya Indonesia ke tahapan transisi menuju demokrasi yang terkonsolidasi. Dalam tahapan ini, ada dua pekerjaan pokok yang harus segera diselesaikan oleh reziem politik baru, yaitu : menata ulang perangkat-perangkat keras dan menata ulang perangkat lunak bagi sistem baru yang lebih baik, ini meliputi beberapa hal barikut. Untuk menata ulang perangkat-perangkat keras ada empat pekerjaan pokok, yaitu : Pertama, pergantian dan perubahan para pelaku dalam sistem itu, dengan memperbanyak pelakupelaku yang lebih bersih dan otentik. Kedua, penataan kembali berbagai lembaga atau institusi dalam masyarakat, termasuk didalamnya partai politik, parlemen pusat serta daerah. Ketiga, memperbaiki dan mengganti aturan-aturan lama dengan aturan-aturan baru yang lebih menjamin keadilan dan kemaslahatan masyarakat. Keempat, membentuk mekanisme-mekanisme yang lebih transparan, adil dan demokratis.
Sedangkan pekerjaan penataan ulang perangkat lunak, dilakukan dengan cara membangun cara berpikir, pola perilaku, tabiat dan kebudayaan lebih trasparan, adil dan demokratis. Misalnya, membangun kesiapan untuk berbeda, berkompetisi secara sehat dan toleransi serta saling menghormati. Jika pekerjaan pertama bisa diselesaikan dalam waktu singkat, tidaklah demikian dengan pekerjaan kedua, penataan perangkat lunak membutuhkan waktu yang lebih lama, tetapi lama atau cepatnya hasil penataan perangkat lunak sangat tergantung seberapa berhasil penataan perangkat keras dalam sistem politik tersebut.

Pembangunan demokrasi politik di tingkat lokal merupakan salah satu prioritas pemerintahan reformasi saat ini, kebijakan otonomi daerah dengan memberikan desentralisasi seluas-luasnya pada daerah, membuktikan bahwa pemerintah Pasca Orde Baru serius melakukan penataan ulang perangkat keras dan perangkat lunak sistem politik. Dengan penataan sistem politik di daerah diharapkan mempercepat proses demokratisasi masyarakat di tingkat lokal, menurut Leo Agustino dan Mohammad Agus Yusoff (2010), memperbincangkan kajian tentang politik lokal akan selalu menarik perhatian, selain karena telah memberikan dampak diametral bagi tarik menarik kepentingan antara pemerintah pusat dan daerah, kondisi politik lokal di 
Indonesia saat ini menunjukan realitas positifnya, dengan dilegalkanya masyarakat untuk memilih kepala daerah secara langsung (pemilukada).

Bagi Kacung Marijan (2010:170-171), ada empat alasan mengapa proses demokratisasi politik di daerah sangat penting bagi arah pembangunan politik di era reformasi saat ini. Pertama, demokrasi pemerintahan di daerah merupakan suatu ajang pendidikan politik yang relevan bagi warga negara di dalam suatu masyarakat demokratis (free societies), karena pemerintah daerah merupakan bagian dari pemerintah yang secara langsung berinteraksi dengan masyarakat ketika proses demokratisasi itu berlangsung. Kedua, pemerintah daerah dipandang sebagai pengontrol bagi perilaku pemerintah pusat yang berlebihan dan berkecenderungan anti demokrasi di dalam suatu pemerintahan yang sentralistik. Kecenderungan kembalinya pemerintah yang anti demokrasi kerap terjadi khususnya pada masa transisi dari pemerintahan yang otoriter menuju pemerintahan yang demokratis. Dalam masa transisi ini pemerintah daerah memiliki posisi tawar menawar yang lebih tinggi atas kekuasaan serta otoritas dengan pemerintah pusat. Dan Ketiga, demokrasi didaerah dianggap mampu menyuguhkan kualitas partisipasi yang lebih baik dibandingkan kalau terjadi ditingkat nasional. Fakta bahwa komunitas di daerah relatif terbatas dan masyaraktnya lebih tahu di antara satu dengan yang lainnya dianggap sebagai dasar argumen bahwa partisipasi masyarakat di daerah itu lebih memungkinkan adanya komunikasi yang lebih langsung di dalam berdemokrasi.

Kebijakan desentralisasi melalui UU No. 22 Tahun 1999 tentang pemerintahan daerah serta revisinya UU No. 32 Tahun 2004 merupakan bentuk dari reformasi politik yang dilakukan pemerintah untuk merespon tuntutan reformasi sistem politik daerah. Bahkan UU No. 32/2004 telah menghadirkan fenomena politik baru selama dua belas tahun terahir ini, yaitu pemilihan kepala daerah secara langsung (pemilukada), menurut Kisno Hadi (Jurnal Ilmu Politik Edisi 21 (Yogyakarta: Pustaka Pelajar, 2010), dengan adanya pemilihan langsung kepala daerah baik bupati/wali kota serta gubernur menjadikan mereka sebagai pejabat negara yang paling menarik perhatian publik. Karena mereka adalah pejabat negara yang paling dekat dengan masyarakat lokal dan diharapkan lebih peka terhadap kebutuhan masyarakat, serta dipercaya lebih mengerti serta memahami kebutuhan lokal ketimbang pemerintah pusat. Bahkan kalau pembangunan daerah dipandang sebagai pondasi pembangunan negara, maka 
kokohnya pembangunan negara tergantung kepada pembangunan di daerah. Oleh sebab itu, harapan pada pemerintah baru pasca pemilukada sangatlah besar untuk menjamin sinergitas hubungan pusat dan daerah dalam merespon tantangan pembangunan politik kedepan.

Tetapi proses demokratisasi di suatu negara tidak selamanya berakhir baik, dengan tercapainya konsolidasi demokrasi, ada kalanya proses transisi itu justru memunculkan pembalikan arus demokratisasi, dengan munculnya praktek-praktek penyimpangan terhadap sistem demokrasi yang semestinya. Menurut Syarif Hidayat (2010), berdasar hasil penelitiannya di beberapa daerah, reformasi desentralisasi serta otonomi daerah yang berlangsung pada kurun waktu terakhir, telah diwarnai anomali terhadap konsep dan kebijakan, yang pada akhirnya melahirkan sejumlah implikasi yang kontra-produktif bagi proses demokratisasi khususnya di daerah. Beliau menyebutkan diantara anomali tersebut ialah pergeseran relasi antara negara dengan masyarakat, seharusnya relasi terjadi dua arah antara negara dan masyarakat, tetapi relasi bergeser pada kompromi yang melibatkan negara dengan elit-elit lokal yang mengatasnamakan masyarakat. Anomali berikutnya, terjadi praktek pemerintahan informal yakni penyelenggara pemerintah daerah lebih banyak dikendalikan oleh kekuatan-kekuatan sosial, ekonomi dan politik di luar struktur formal pemerintahan, baik yang dilkendalikan oleh kalangan pengusaha maupun tokoh elit masyarakat.

Fenomena anomali dapat kita lihat dari proses pergeseran relasi antara masyarakat dengan negara, pasca reformasi masyarakat tidak lagi sepenuhnya terpinggirkan, baik dalam proses pengambilan keputusan maupun dalam pelaksanaan kebijakan. Tetapi peran masyarakat dalam arti riil sebagai civil society belum terwujud, peran politik tersebut telah diambilalih oleh lapisan elit masyarakat, sehingga proses pengambilan keputusan ditingkat daerah lebih banyak diwarnai koalisi serta tawar-menawar kepentingan para elit masyarakat dengan para elit penyelenggara negara. Relasi yang seharusnya terjadi dua arah antara state dengan society dalam proses pengambilan keputusan serta implementasi kebijakan tidak terjadi, pola pergeseran relasi antar elit masyarakat dan penyelenggara negara tidak lagi menempatkan posisi negara sebagai institusi yang menyerap tuntutan dari bawah. Namun, pengambilan keputusan tersebut lebih didominasi artikulasiagregasi kepentingan lapisan elit penguasa yang berkolaborasi dengan elit masyarakat. 
Vol.4, No.1, April 2018

\section{PEMBAHASAN}

\section{Civil Society, Shadow State dan Local Strongmen.}

Munculnya praktik pemerintahan informal (informal governance), yakni penyelenggara pemerintahan yang lebih banyak dikendalikan oleh kekuatan sosial, ekonomi dan politik diluar struktur formal pemerintahan. Praktik informal governance ini dilabeli dengan terminologi Shadow State oleh beberapa ilmuwan politik. Menurut Syarif Hidayat (Jurnal Ilmiah STIAMI), terdapat empat karakteristik umum dari praktik praktik informal governance dan Shadow State. Pertama, bahwa fenomena ini hadir, tumbuh dan berkembang sebagi akibat dari terjadinya pelapukan fungsi dari insitusi formal (negara). Kedua, akumulasi keuntungan ekonomi dan politik jangka pendek di luar bingkai regulasi formal, merupakan tujuan utama dari transakasi melalui informal market. Pada konteks inilah masing-masing pihak akan memaksimalkan sumber daya yang dimiliki. Ketiga, modus operasi atau mekanisme kerja dari informal governance cukup bervariasi, yang secara umum dapat dibedakan dalam dua kategori utama : melalui manipulasi kebijakan publik dan melalui jaringan aliansi antarpersonal, maupun aliansi antar lembaga. Keempat, aktor (pelaku) yang terlibat dalam informal pemeritahan ialah para penyelenggara negara dan aktoraktor dalam masyarakat, para pelaku yang disebut terakhir ini sangatlah beragam menunjuk para pengusaha, politisi dari partai politik, tokoh ormas dan bahkan para pelaku kriminal.

\section{Gambar 1. Shadow State Dalam Pelaksanaan Pemilukada}

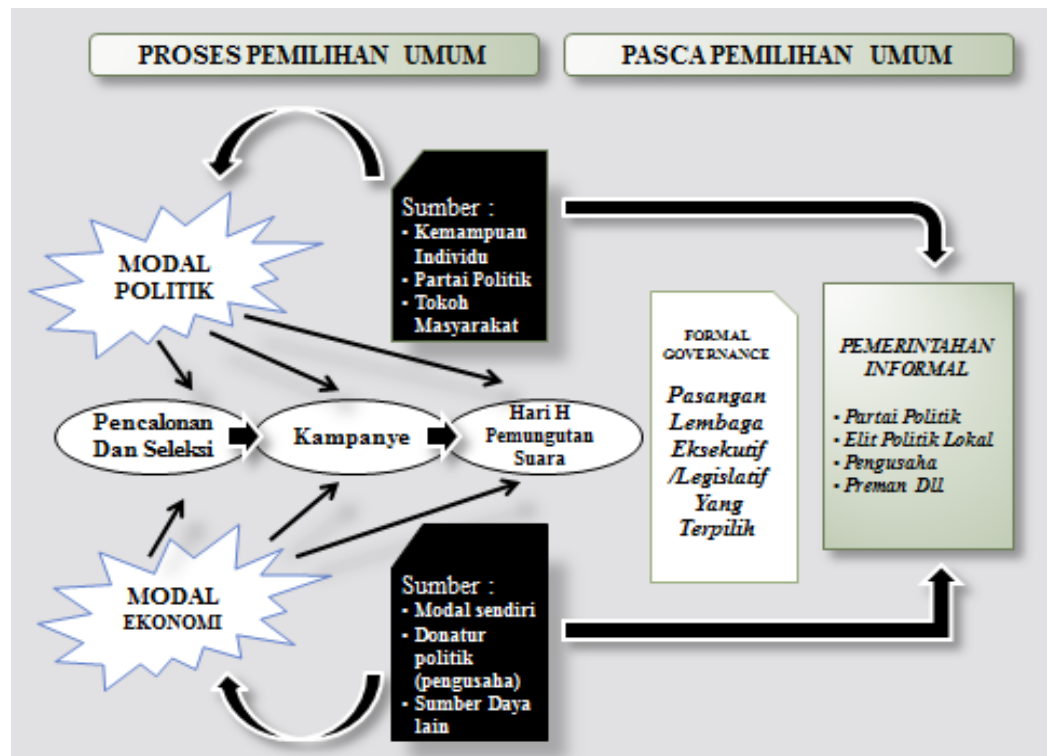

Sumber : Syarif Hidayat, Bisnis dan Politik Dlm Penyelenggaraan Daerah Pasca Pilkada, Jurnal Ekonomi dan Pembangunan, Vol XV, Th 2007 
Salah satu faktor penyebab menguatnya gejala pemerintahan informal adalah munculnya aktor shadow state dari local strongmen. Bagi penulis fenomena local strongmen sangat menarik untuk dikaji dari awal kemunculannya, salah satu penelitian yang membahas cukup detail tentang kemunculan local strongmen ialah penelitian yang dilakukan oleh Leo Agustino dan Mohammad Agus Yussof (2011:20-22), menurut mereka kemunculan local strongmen tidak bisa dilepaskan dari sejarah sistem politik Orde Baru, para tokoh local strongmen ini menurut mereka, merupakan orang-orang lama yang memiliki sumber kapital tidak terbatas, hanya karena faktor kesempatan mereka tidak bisa tampil saat Orde Baru berkuasa, mengingat reziem Orde Baru melakukan sistem dropping, sehingga para aktor-aktor lokal ini kalah bersaing dan baru bisa muncul serta eksis setelah reziem orde baru runtuh. Kemampuan kapital yang mereka miliki menjadi modal besar yang mengantarkan mereka menjadi penguasa baru (formal atau informal) menggantikan penguasa lokal yang sebelumnya merupakan dropping dari pusat.

Melalui proses demokratisasi dan desentralisasi, para local strongmen memperoleh kesempatan untuk menjabat kursi sentral di lembaga-lembaga pemerintahan di daerah dibandingkan masa-masa sebelumnya. Kalaupun mereka tidak menduduki jabatan-jabatan penting tersebut menurut Leo Agustino dan Mohammad Agus Yussof (2011:2022), para broker atau orang kuat lokal ini selalu berupaya untuk memastikan bahwa para politisi lokal tergantung pada bantuan serta sokongan agar kebijakan pemerintah daerah menguntungkan bisnis dan posisinya. Imbas jasa para politisi kepada para broker politik tidak jarang dilandasi pada jasa investasi politik selama berlangsungnya proses pilkada.

Selain menghadirkan fenomena adanya orang kuat daerah juga menunjukan implementasi dari hadirnya pola politik kartel di daerah. Politik kartel menggambarkan suasana politik yang berjalan relatif damai atau tanpa persaingan ketat, misalnya dalam penentuan bakal calon kepala daerah oleh partai politik untuk mendapatkan dukungan suara dari beberapa elemen dalam masyarakat yang dinilai dapat mempengaruhi suara mayoritas masyarakat. Bentuk kartel lazim digunakan dalam menganalisis fenomena ekonomi di mana terjadi koordinasi untuk meminimalisi persaingan, mengontrol harga dan memaksimalkan keuntungan diantara anggota kartel. Tetapi dibalik itu, praktik politik uang dan kolusi antar anggota kartel yang terlibat hendak mengambil keuntungan dari hasil akhir proses kartelisasi menjadi tidak terelakan 
Dalam konteks pilkada (pemilukada) menurut Kisno Hadi (2011), politik kartel dapat dilihat dari tiga mekanisme ; (1) kartelisasi melalui peran elemen civil society seperti organisasi keagamaan, media massa lokal dan beberapa organisasi kemasyarakatan terutama paguyuban berdasar etnis dan agama. Elemen civil society ini menyadari dengan terlibat dalam kartel akan ada sesuatu keuntungan yang dapat diraih nanti, bisa berupa finansial ataupun pengakuan sosial dari kontestan pemenang pilkada, (2) kartelisasi melalui peran birokrasi di mana pejabat-pejabat birokrat secara terbuka ataupun tertutup terlibat dalam lingkaran kartel, mereka melakukan investasi dengan menyokong pendanaan pencalonan para calon melalui cara-cara unik yang khas lokal. Bagi para birokrat yang sedang menjabat paling kurang ia tidak kehilangan jabatannya atau memperoleh jabatan baru yang lebih basah takala kandidat yang disokongnya menang, (3) kartelisasi melalui peran elit ekonomi lokal maupun nasional, para pengusaha dengan cara ditawar atau menawarkan diri terlibat dalam proses konstestasi politik, dengan membiayai kampanye kandidat, mereka melakukan proses investasi untuk mendapatkan jaminan dan pengakuan dalam proses berinvestasi.

Menurut penulis salah satu cara mengurangi anomali desentralisasi politik ditingkat lokal ialah memperkuat partisipasi politik masyarakat untuk melakukan pengawasan terhadap jalannya pemerintahan di daerah. Kekuataan masyarakat ini tentunya akan efektif menjadi salah satu kekuataan politik di tingkat lokal kalau masyarakat ini menghimpun ke dalam bentuk organisasi-organisasi atau asosiasiasosiasi. Keterlibatan masyarakat dalam organisasi-organisasi atau asosiasi-asosiasi untuk melakukan pengawasan atau kontrol terhadap jalannya pemerintahan lokal dalam teorisasi ilmu politik dimasukan sebagai kekuataan civil society.

Wacana tentang civil society dalam khasanah literatur ilmu politik sebenarnya berasal dari barat, berdasarkan penulusuran berbagai literatur yang membahas tentang civil society, penulis menemukan definsi yang sangat beragam seperti misalnya : masyarakat berbudaya, masyarakat madani, masyarakat politik, masyarakat beradab dan masyarakat kewargaan (Anas Urbaningrum, 1997).

Civil Society menurut Larry Diamond (Rethinking Civil Society : Toward Democratic Consolidation), dipahami sebagai bidang kehidupan sosial yang terorganisir yang bersifat sukarela, menghasilkan diri, sebagian besar otonom atau mandiri dari entitas negara serta terikat tatanan hukum atau seperangkat aturan bersama. Pengertian ini tentunya sangat berbeda dari "masyarakat" 
pada umumnya, karena civil society melibatkan warga untuk bertindak secara kolektif dalam ruang-ruang publik untuk menyatakan minat, semangat, bertukar informasi, mencapai tujuan bersama dan membuat segala tuntutan pada negara.

\section{Pengertian dari Larry} Diamond tidak berbeda dengan pengertian dari para ilmuwan politik Barat lain, seperti misalnya Ernest Gellner yang menekankan adanya otonomi atau kemandirian yang harus ada sebagai prasyarat mutlak suatu masyarakat dikatakan sebagai civil society. Bagi Diamond, civil society merupakan suatu entitas perantara yang berdiri diantara pribadi (personal) dengan negara, dari pemilahan ini Diamond hendak membuat garis pemisah yang tegas antara entitas negara dengan masyarakatnya, masing-masing berdiri dengan tingkat otonomisasi yang berbeda, civil society membutuhkan perlindungan dari tatanan hukum yang dilembagakan untuk menjaga otonomi mereka dan kebebasan bertindak.

Dengan demikian civil society tidak hanya membatasi kekuasaan negara, tetapi otoritas negara yang sah ketika otoritas yang didasarkan pada aturan hukum, tentunya ketika negara itu sendiri tidak taat hukum dan menghina hak otonomi yang dimiliki individu, kelompok dan masyarakat. Konsep civil society menurut penulis seperti oposisi permanen yang hadir ditengah-tengah besarnya kekuasaan negara, ia menjadi kekuataan penyeimbang yang cukup besar setelah dominasi otoritaif negara, dalam konsep civil society yang ideal tentunya tidak hadir untuk memperkecil peran politik negara, karena kalau peran politik negara menjadi lemah saat berhadapan dengan masyarakatnya akan mengakibatkan masyarakatnya anarkis, dan sebaliknya bila peran negara terlampau besar akan mengarah pada otoriter. Artinya civil society tidak dapat dibiarkan tanpa sebuah kontrol, maka untuk mencari garis tengah diantara keduanya tentu dua entitas ini (civil society dan negara) harus diletakan pada fungsinya masing-masing yang proporsional.

Organisasi atau asosiasi merupakan representasi dari civil society yang independen, menjadi keniscayaan bagi masyarakat untuk membentuk organisasi-organisasi atau asosiasi-asosiasi warga negara yang mandiri, karena hanya melalui cara demikian penyalahgunaan kekuasaan oleh negara dapat dicegah, memang negara yang aktif dan kuat juga diperlukan, tapi bukan berarti demokrasi harus dibina oleh negara. Demokrasi hanya dapat tumbuh dan berkembang dengan tumbuhnya kesadaran civil society, melalui kontrol dari masyarakat inilah maka despostisme monopoli kekuasaan negara dapat dicegah, 
maka dengan adanya asosiasiasosiasi tersebut mengekspresikan adanya prulalitas di dalam masyarakat.

Di Indonesia yang menjadi salah satu representasi civil society ialah berbagai organisasi nonpemerintah (ornop). Ornop merupakan organisasi yang dibentuk oleh kalangan yang bersifat mandiri, organisasi ini tidak menggantungkan diri pada pemerintah, terutama dukungan finansial.Ornop dibentuk sebagai perwujudan dari komitmen sejumlah warga negara yang mempunyai keperdulian terhadap persoalan-persoalan yang muncul baik dalam bidang ekonomi, sosial maupun politik. Demokrasi dan civil society seperti dua sisi dari satu mata uang yang sama, keduanya eksis secara bersama civil society yang tidak dapat dipisahkan satu dengan lainnya. Suatu negara dikatakan demokratis bila ada suatu kekuataan aktif dari civil society yang mampu membatasi kekuasaan negara. Dalam sebuah negara demokratis, kekuasasan negara harus mendapat persetujuan civil society dalam membuat serta mengimplementasikan kebijakankebijakannya. Sebaliknya, juga memerlukan negara yang efektif dalam melaksanakan tuntutannya. Oleh karena itu, di negara yang demokratis, kualitas negara tergantung pada kualitas dari civil society-nya, demikian juga sebaliknya (Luthfi J. Kurniawan dan Hesti Puspitosari, 2012:1).

Masyarakat sipil (civil society) dipahami sebagai bidang kehidupan sosial terorganisir yang bersifat sukarela, otonom atau mandiri dari entitas negara serta terikat dengan tatanan hukum atau seperangkat aturan bersama. Pengertian ini tentunya sangat berbeda dari "masyarakat" pada umumnya, karena masyarakat sipil melibatkan warga untuk bertindak secara kolektif dalam ruang-ruang publik untuk menyatakan minat, semangat, bertukar informasi, mencapai tujuan bersama dan membuat segala tuntutan pada negara. Sedangkan ilmuwan politik barat seperti Ernest Gellner, menekankan bahwa civil society itu merupakan entitas yang otonom atau mandiri, konsep otonomi atau kemandirian ini menjadi titik penting dalam konsep masyarakat sipil.

Masyarakat sipil (civil society) memiliki tiga komponen inti, yaitu otonomi, akses masyarakat dan arena publik terbuka. Dengan otonomi dimaksudkan bahwa civil society haruslah sebuah masyarakat yang terlepas sama sekali dari pengaruh negara, apakah itu dalam bidang ekonomi, politik ataupun sosial. Dalam masyarakat seperti itu, segala bentuk kegiatannya sepenuhnya bersumber dari masyarakat itu sendiri, tanpa ada campur tangan dari negara. Artinya, kemandirian dalam melakukan 
kegiatan dan kemandirian dari intervensi negara. Komponen kedua dari civil society adalah akses masyarakat terhadap lembaga negara, setiap warga negara baik secara sendiri-sendiri maupun kelompok, harus mempunyai akses terhadap aktor di dalam pemerintahan, maksudnya setiap individu dapat melakukan partisipasi politik dengan berbagai bentuk, apakah dengan cara menghubungi pejabat untuk menyampaikan aspirasi, menulis pikiran di media massa bahkan dengan cara unjuk rasa, agar mendapat perhatian secara luas dari pemerintah. Kemudian kalangan pemerintahan harus memberikan komitmennya untuk mendengar, menerima keluhan masyarakat untuk diteruskan dalam mengambil langkah-langkah kongkret. Komponen terakhir adalah arena publik yang otonom, dimana selain berbagai macam organisasi kemasyarakatan dapat mengatur dirinya sendiri, juga tersedia ruang publik, sebuah tempat bagi masyarakat untuk mengembangkan dirinya secara maksimal dalam segala aspek kehidupan, arena publik ini prinsipnya harus terlepas dari campur tangan negara (Afan Gaffar, 2006 : 181-183).

\section{Pembahasan}

tentang

masyarakat sipil (civil society) tentu tidak bisa dilepaskan dari keberadaan Lembaga Swadaya Masyarakat (LSM), Organisasi Masyarakat (Ormas) atau Non Government
Organizations (NGO) yang merupakan elemen-elemen pembentuk dari civil society.

LSM atau organisasi non pemerintah (ornop) merupakan organisasi yang dibentuk oleh kalangan masyarakat yang bersifat mandiri, organisasi seperti ini tidak menggantungkan diri kepada pemerintah, terutama dalam dukungan finansial dan sarana prasarana. Organisasi ini dibentuk sebagai perwujudan dari komitmen sejumlah warga negara yang mempunyai keperdulian terhadap persoalan-persoalan yang muncul, baik dalam bidang ekonomi, sosial maupun politik. Misalnya kalangan aktifis dalam bidang teknologi mempunyai perhatian untuk mengangkat nasib masyarakat petani dengan memperkenalkan teknologi tepat guna. Kalangan perduli nasib kaum buruh mendirikan organisasi yang membantu kalangan buruh, demikian juga dengan sejumlah aktifis perempuan yang membentuk sejumlah organisasi yang melindungi kaum perempuan dari berbagai diskriminasi dalam kehidupan sosial. Kehadiran Ornop dalam sebuah masyarakat merupakan kenyataan yang tidak dapat dinafikan, hal itu terjadi karena bagaimanapun juga kapasitas pemerintah sangat terbatas. Tidak semua kebutuhan masyarakat dapat dipenuhi oleh pemerintah, apalagi di negara-negara dunia ketiga, seperti Indonesia (Afan Gaffar, 2006 : 200-202). 
Selanjutnya, ide civil society menghendaki institusi-insitusi non pemerintah ini berada pada sektor publik, yang berbentuk forum-forum representatif atau berupa asosiasiasosiasi bersifat terbuka, inklusif dan menjamin kebebasan bagi masyarakat untuk menyampaikan keinginannya.

Terdapat empat peranan yang dapat dimainkan oleh kalangan Ornop dalam sebuah negara, antara lain : (1) Memonitoring pelaksanaan penyelenggaraan negara, bahkan bila perlu melakukan aksi protes, hal ini terjadi karena penyalanggunaan kekuasaan yang dilakukan para pejabat pemerintahan. (2) Katalisasi perubahan sosial, hal ini dilakukan dengan jalan mengangkat sejumlah masalah yang penting dalam masyarakat, membentuk kesadaran global, melakukan advokasi demi perubahan kebijakan negara, mengembangkan kemauan rakyat dan mendorong inisiatif pemerintah.

(3) Memfasilitasi rekonsiliasi warga negara dengan lembaga peradilan. Hal ini dilakukan karena warga mayarakat menjadi korban ketidakadilan, kalangan ornop muncul secara aktif melakukan pembelaan bagi mereka yang menjadi korban ketidakadilan. (4) Implementasi program pelayanan, ornop dapat menempatkan diri sebagai lembaga yang mewujudkan sejumlah program pemerintah (Afan Gaffar, 2006 : 204).
Dalam konteks politik lokal tentu saja kehadiran civil society sangatlah penting sebagai penyeimbang atas dominasi pemerintah daerah, kekuataan masyarakat sipil ini harus mampu melakukan pengawalan serta pengontrolan terhadap setiap kebijakan yang diputuskan pemerintah. Peran ornop dalam dinamika politik lokal mengambil posisi berada di tengah, diantara sektor negara, pasar dan masyarakat. Ornop harus tetap menempati posisi di tengah, sebagai pihak yang netral dalam mendorong proses perubahan. Peran-peran ornop tersebut misalnya sebagai fasilitator bagi proses membangun kesadaran publik, menjadi negosiator bagi kepentingan publik, bahkan menjadi aktor parlemen jalanan sebagai pengawas bagi negara. Ornop merupakan organisasi swadaya yang didirikan oleh sekelompok orang untuk memperjuangkan kepentingan masyarakat, dengan kata lain ornop bertugas untuk memperkuat masyarakat dalam menghadapi dominasi negara, swasta atau koorporasi modal internasional. Berikut beberapa tugas ornop dalam konteks pembangunan demokratisasi di tingkat lokal menurut Sunyoto Usman (2015:125) :

1. Peran pendidikan yang dilakukan oleh ornop melalui pemberian kesadaran terhadap rakyat 
tentang proses demokrasi yang tengah berlangsung.

2. Ornop dapat memunculkan isu lingkungan, hak asasi manusia dan kemiskinan yang nantinya dapat disuarakan kepada pemerintah supaya membuat kebijakan yang berpihak kepada kepentingan rakyat.

3. Memobilisasi rakyat untuk memaksa pemerintahan supaya lebih transparan dalam menjalankan pemerintahan.

4. Melakukan pemantauan terhadap implementasi serta akibat kebijakan yang diambil ditingkat global, organisasi masyarakat sipil dapat mendorong otoritas di tingkat global agar lebih bertanggungjawab terhadap publik atas tindakan serta kebijakan yang telah diambilnya.

Itulah beberapa point penting tentang konsep civil society dalam perannya memberikan kontribusi terhadap pembangunan demokratisasi ditingkat lokal, representasi civil society yang berupa ornop ini sudah semestinya terus menerus memberikan kasadaran emansipatoris kepada masyarakat tentang pentingnya melakukan kontrol terhadap jalannya roda pemerintahan di daerah. Tentu, agar peran ornop ini tetap terjaga independensinya, ornop tersebut haruslah memiliki karakter swadaya, artinya tidak tergantung terhadap pihak lain, dalam hal pendanaan dan kegiatan. Artinya dukungan materil sepenuhnya berasal dari hasil swadaya masyarakat, sehingga independensi ornop itu tetap terjaga ketika berhadap-hadapan dengan negara atau pihak swasta.

\section{KESIMPULAN}

Konsep civil society dalam perkembangan kontemporer menjadi kebutuhan yang mendesak bagi proses pembangunan demokratisasi ditingkat lokal, terlebih di era desentralisasi ini masyarakat diberikan ruang partisipasi selebarlebarnya untuk turut serta dalam proses pembangunan di daerah. Ornop yang menjadi representasi civil sociey sudah seharusnya memberikan banyak kontribusi bagi dinamika politik lokal, peran ideal yang harus ditampilkan ornop ini, yaitu menjadi kekuataan penyeimbang dari dominasi negara, peran sebagai penyeimbang ini akan menjadi peran yang maksimal bila eksistensi ornop murni dari hasil swadaya masyarakat, bukan bantuan dari pihak swasta atau pemerintah. Demokratisasi ditingkat lokal akan berjalan dengan baik, apabila ruang partisipasi politik masyarakat melalui wadah civil society terbuka dengan lebar.

\section{DAFTAR PUSTAKA}


Agustino, Leo dan Mohammad Agus Yusoff. (2010). Politik Lokal Di Indonesia : Dari Otokratik Ke Reformasi Politik. Dalam Jurnal Ilmu Politik Edisi 21. Yogyakarta: Pustaka Pelajar.

Culla, Adi Suryadi. (1999). Masyarakat Madani: Pemikiran, Teori dan Relevansinya Dengan CitaCita Reformasi. Jakarta: Rajawali Press.

Fatah, Eep Saefulloh. (2000). Zaman Kesempatan: Agenda-Agenda Besar Demokratisasi Pasca Orde Baru. Bandung: Mizan.

Gaffar, Afan, Politik Indonesia : Transisi Menuju Demokrasi. (Yogyakarta : Pustaka Pelajar, 2006).

Hadi, Kisno. (2011). Politik Kartel Dalam Pilkada Kalimantan Tengah dalam Jurnal Ilmu Politik edisi ke-21. Yogyakarta: Pustaka Pelajar.

Hidayat, Syarif. (2010). Pemekaran Daerah, Pilkada dan
Pergeseran Relasi Antar Elit. Dalam Abdul Malik Gismar dan Syarif Hidayat (editor), Reformasi Setengah Matang. Bandung: Teraju.

Hidayat, Syarif, Pilkada Langsung dan Budaya Shadow State: Perspektif Ekonomi Politik. (Jurnal Ilmiah STIAMI).

Marijan, Kacung. (2010). Sistem Politik Indonesia : Konsolidasi Demokrasi Pasca Orde Baru. Jakarta: Kencana.

O’Donell, Guillerno. (1993). Transisi Menuju Demokrasi: Rangkaian Kemungkinan dan Ketidakpastian. Jakarta: LP3ES.

Sunyoto, Usman. (2015). Esai Perubahan Sosial. Yogyakarta: Pustaka Pelajar. Urbaningrum, Anas. (1997). Menuju Masyarakat Madani: Pilar dan Agenda Reformasi. Jakarta: Yarsif Watampone. http://persatuanindonesia.or.id/profil 